\title{
Historical perspectives of The American Association for Thoracic Surgery: Thomas L. Spray
}

\author{
James S. Tweddell, MD
}

\footnotetext{
From the Department of Cardiothoracic Surgery, Cincinnati Children's Hospital Medical Center; and University of Cincinnati, Cincinnati, Ohio.

Disclosures: Author has nothing to disclose with regard to commercial support.

Received for publication June 13, 2016; accepted for publication June 13, 2016; available ahead of print July 20, 2016.

Address for reprints: James S. Tweddell, MD, Department of Cardiothoracic Surgery, Cincinnati Children's Hospital Medical Center, 3333 Burnet Ave, Cincinnati, OH 45229 (E-mail: James. Tweddell@CCHMC.org). J Thorac Cardiovasc Surg 2016;152:945-9

$0022-5223 / \$ 36.00$

Copyright (C) 2016 Published by Elsevier Inc. on behalf of The American Association for Thoracic Surgery http://dx.doi.org/10.1016/j.jtcvs.2016.06.019
}

Thomas L. Spray was the 89th president of The American Association for Thoracic Surgery (AATS) and served during the 92nd year of the Association (Figure 1). His presidency took place on the eve of enormous changes in our health care system, particularly the development and use of administrative databases to assess outcomes and quality. His presidential address, "The Quality Conundrum," delivered on May 11, 2009, spoke of the many divergent and contradictory challenges faced by cardiothoracic surgeons today and how we as a specialty can move forward and model quality. ${ }^{1}$

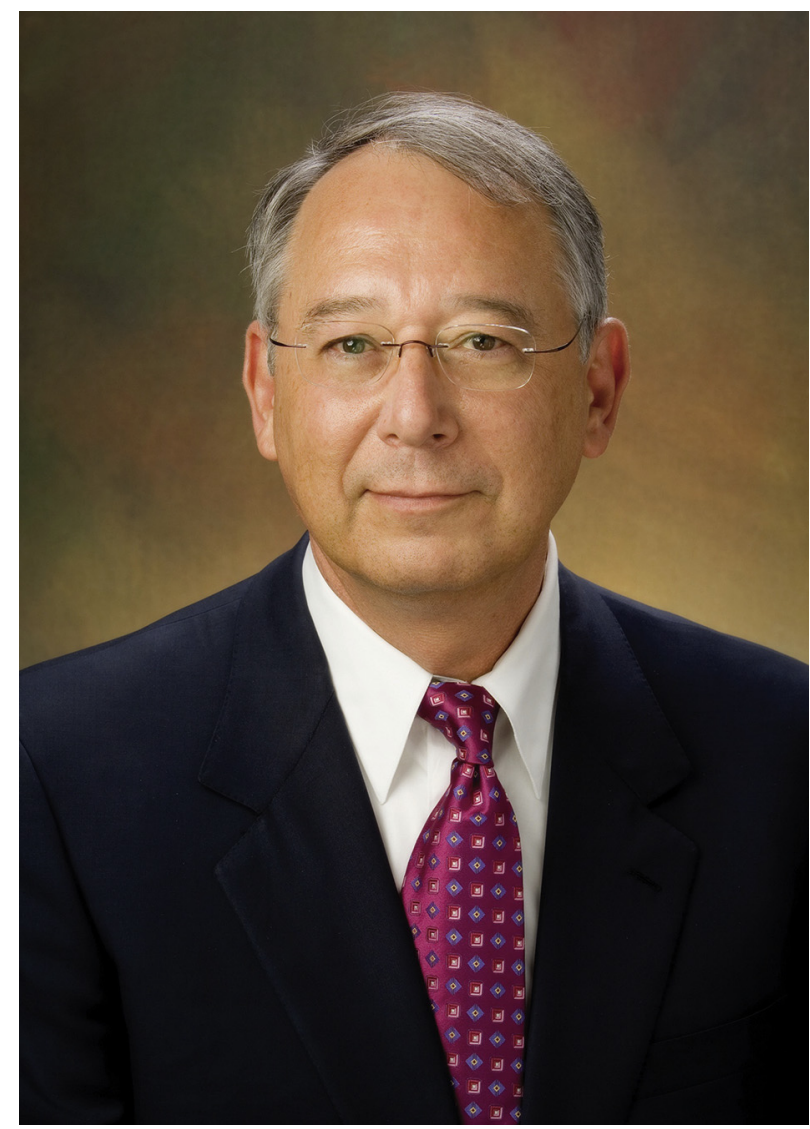

FIGURE 1. Thomas L. Spray, MD, the 89th president of the AATS.

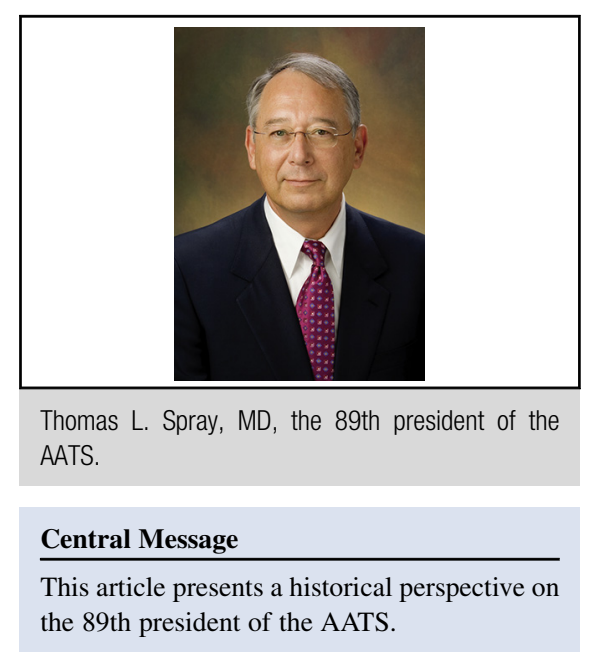

Thomas L. Spray was born August 28, 1948, in Rochester, Minnesota. At the time, his father was a resident in orthopedic surgery at the Mayo Clinic. After his father, Paul Spray, completed his training, the Spray family moved to Oak Ridge, Tennessee, where he entered private practice in orthopedic surgery (Figure 2). In his presidential address, Dr Spray credits his father's example as his primary inspiration to pursue a career in medicine and ultimately cardiothoracic surgery. He witnessed firsthand his father's commitment to his patients - "the long hours, the warmed-over dinners and the late night calls to the emergency room." He was fortunate to accompany his father on medical mission trips to places such as Algeria and witnessed firsthand his father's commitment to relief of suffering and to training other surgeons.

Tom Spray left Oak Ridge to attend Haverford College, a liberal arts school in the suburbs of Philadelphia, at the time an all-male Quaker school. He had a strong interest in molecular biology and was attracted to Haverford because of the unique opportunity to obtain hands-on experience with an electron microscope, a rare opportunity indeed for an undergraduate student. At Haverford, he gained valuable experience preparing specimens for electron microscopy. He participated actively in research and was an author of an article in Immunology while an undergraduate. ${ }^{2}$ As part of an exchange program, he spent half of his senior year at Vassar; perhaps this was payback for 3.5 years at an all-male college. His senior thesis was on interferon, and he graduated cum laude, a rare achievement for Haverford. 


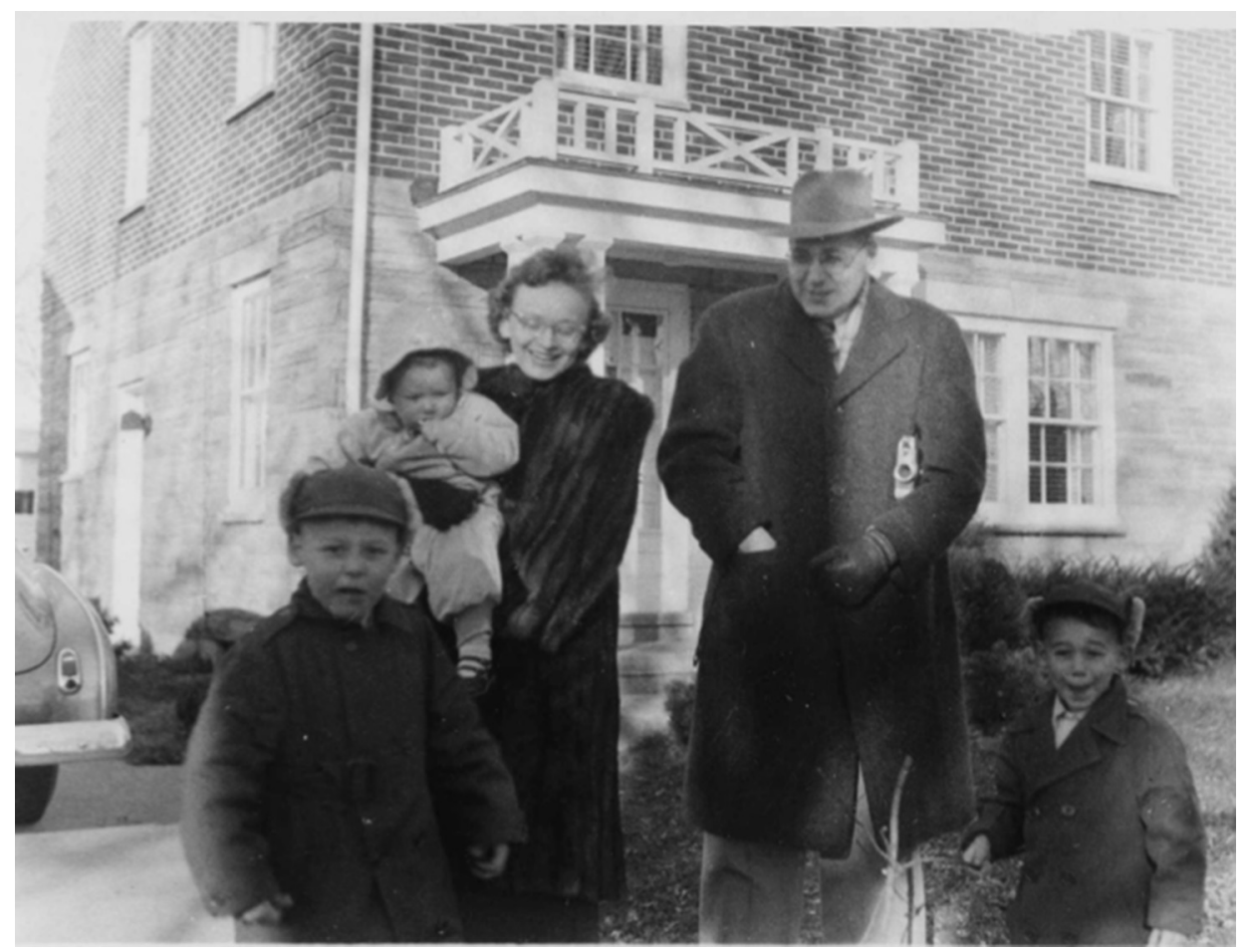

FIGURE 2. Dr Spray's family. From left to right: his brother David, his mother Louis holding his sister Lynn, his father Dr Paul Spray, and young Tom Spray.

Tom Spray entered the Duke University School of Medicine in 1970. He counted himself as fortunate to have been accepted to a medical school as prestigious as Duke. During his third year of medical school, his experience with electron microscopy paid off, and he was able to participate in research on calcium flow in cardiac muscle. This work resulted in 2 publications in The Journal of Cell Biology. ${ }^{3,4}$

Dr Spray entered surgical training at Duke University in 1973 under Dr David C. Sabiston (66th president of the AATS). He was 1 of 22 interns accepted into the pyramid program at Duke. At the time, outstanding Duke University Medical Students who matched in surgery could get a 6month head start on their internship, and Dr Spray was admitted into the "early internship" program. At the time, Duke was a leader in the developing field of cardiac surgery. In addition to Dr Sabiston, his colleagues at Duke included many leaders in this new field of cardiac surgery, including Will C. Sealy, D. Glenn Young, Andrew S. Wechsler, H. Newland Oldham, and future presidents of the AATS: Paul A. Ebert (68th president), James L. Cox (81st president), and Fred A. Crawford (83rd president). After 2 years, Duke surgery residents went into laboratory research. The ideal position for a resident interested in cardiothoracic surgery was a position in the Surgical Branch of the National Institute of Health (NIH), National Heart, Lung, and Blood Institute (NHLBI), but because of his admission to the early internship program Dr Spray was out of sequence for this opportunity. Dr Spray had developed a friendship with a junior attending at Duke, Samuel A. Wells, who would go on to become Chair of the Department of Surgery at Washington University in St Louis. Dr Wells had just returned from the NIH and recommended Dr Spray to William C. Roberts at the NIH/NHLBI Pathology Branch. Dr Spray served 2 years at the NIH/NHLBI. Among his work with Dr Roberts was preparation of heart specimens in a way that was anatomically accurate and consistent with views that might be obtained during cardiac surgery. His time at the NIH was extremely productive and resulted in more than 20 publications. Among these were the first descriptions of early degeneration of tissue valves. ${ }^{5-7}$ Once again his ability with electron microscopy proved to be beneficial, and he was able to demonstrate the degeneration of tissue valves using both transmission and scanning electron microscopy. On the basis of his experience with Dr Roberts, while only a first year senior resident, Dr Spray sat alongside legends of heart surgery-Alain F. Carpentier, Viking O. Bjork, Albert Starr, and William $\mathrm{H}$. Muller, $\mathrm{Jr}$ - as a member of a panel of experts on the topic of tissue valve degeneration at the American College of Surgeons.

Dr Spray's advanced technical skills and interest in congenital heart disease had been recognized at Duke during his surgical training. In 1983, Dr Spray was recruited by Sam Wells and James L. Cox directly out of the residency program at Duke to join the faculty at Washington University in St Louis and lead the congenital heart surgery program at the St Louis Children's Hospital (Figure 3). 


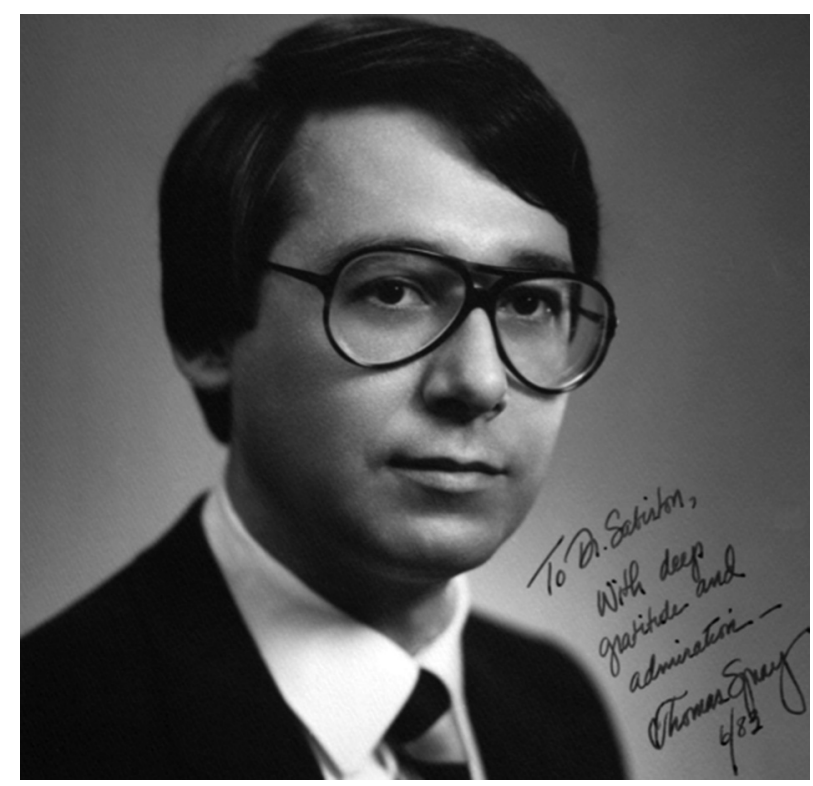

FIGURE 3. Tom Spray after completing his residency at Duke University and on the eve of his arrival at Washington University.

During his first year out of residency, Dr Spray sought mentorship from other congenital heart surgeons. He spent time observing James Alexander, MD, a fellow graduate of the Duke training program and congenital heart surgeon at University of Florida in Gainesville. He traveled abroad and visited Marc de Leval at Great Ormond Street in London and Francis Fontan in Bordeaux, France. He remembered fondly how these world figures in congenital heart surgery were extremely gracious to, at the time, a little known junior surgeon from St Louis and how they spent hours reviewing cases with him. Those friendships with Dr de Leval and Dr Fontan continue to this day.

Dr Spray quickly threw himself into this work at St Louis Children's Hospital. They established an extracorporeal membrane oxygenation (ECMO) program, the third in the nation at that time. He was an early adopter of ECMO for postcardiotomy circulatory support. ${ }^{8}$ At the first ELSO meeting, he presented their experience on reconstruction of the carotid artery and jugular veins after ECMO decannulation. Dr Spray and colleagues were among the first to use intraoperative echocardiography to evaluate repair of congenital heart defects. ${ }^{9}$ They began a pediatric heart transplant program in 1986 and were among the first programs to pursue heart transplantation for treatment of hypoplastic left heart syndrome. ${ }^{10,11}$ Although Dr Spray is a world figure in congenital heart surgery, during his first 10 years at Washington University and Barnes Hospital he was also performing a large number of surgeries for acquired heart disease. He began the mitral valve repair program at Barnes Hospital. He was an early adopter of the Ross operation for aortic valve replacement, a technique he quickly applied to children, including neonates. ${ }^{12,13} \mathrm{In}$
1990, he performed the first successful pediatric lung transplant at St Louis Children's Hospital. Within a short period of time, they had established the largest and most successful pediatric lung transplant program in the world. There were a number of firsts, including the first lung transplant for surfactant B deficiency, congenital pulmonary vein stenosis, and tetralogy of Fallot with pulmonary atresia and major aortopulmonary collaterals, and the first ECMO bridge to lung transplant. ${ }^{14-19}$

As a resident and firsthand witness to the cardiothoracic surgery program at Washington University, Barnes-Jewish Hospital, and St Louis Children's Hospital, it is here that I will depart from a third-person perspective and provide some firsthand recollections of this very special time. Under the direction of James L. Cox, the cardiothoracic surgical program at Washington University was arguably the most advanced and accomplished in the world at the time. We had giants in the field working side by side; in addition to Dr Cox we had Joel Cooper (84th president of the AATS), Larry Kaiser, Alec Patterson (90th president of the AATS), Thomas B. Ferguson (62nd president of the AATS and president of The Society of Thoracic Surgeons 19761977), Nick Kouchoukos (president of The Society of Thoracic Surgeons 1999-2000), and Tom Spray. It seemed every week we were performing a "first-of-its-kind" operation. This was an amazing place to be a cardiothoracic surgery resident. We were well trained, well educated, and made to feel part of the team. Although it was hard work and long hours, there was a particular joy in the exhaustion.

At Washington University and St Louis Children's Hospital, I was extraordinarily fortunate to be Dr Spray's first congenital heart surgery fellow. It is difficult to describe your impressions when you see a true virtuoso, whether in sports, music, or surgery. Terms such as skillful, smooth, and effortless are used, but I would suggest that, to paraphrase Dr Spray's presidential address in which he in turn paraphrases Justice Potter Stewart, "you know it when you see it." We witness it in slow-motion replays in sports, but here the athletes have had countless hours of practice. We watch musical performances, but again the instrumentalists have had hours of rehearsal. In surgery, it is something else entirely. In the operating room, the stakes are very high with no chance to practice the specific operation being performed, and frequently we have the newest and most precious member of the family in front of us on the table. The congenital heart surgeon works within the overlap of the strangest Venn diagram of human qualities, unparalleled skill, in-depth knowledge, unwavering commitment, and yet a degree of emotional detachment. I doubt I will ever witness another surgeon like Tom. His motions were deliberate, adroit, but also fast. Simply put, Tom was a natural.

Sometimes training under a "natural" may not be the best place to find oneself; after all, athletes and musicians at the highest level rarely give lessons; indeed, many times 


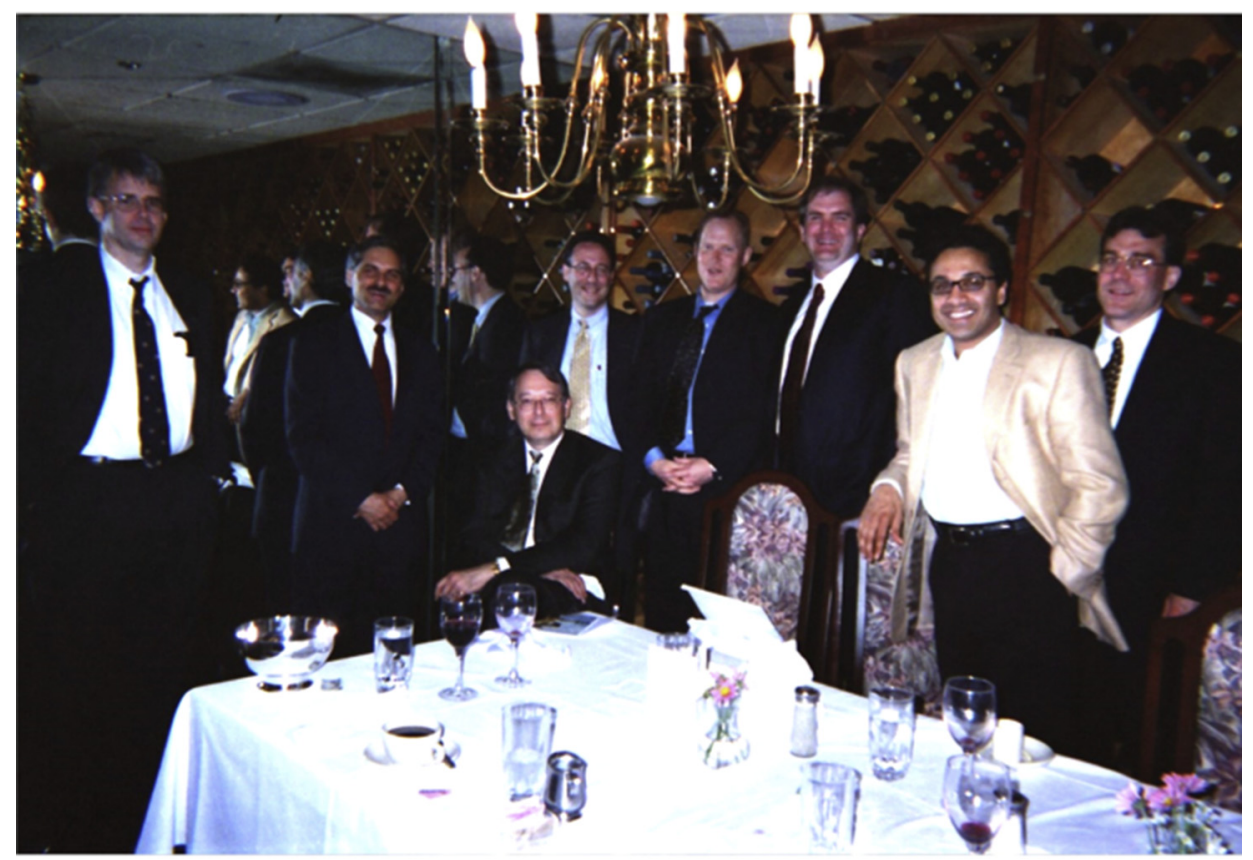

FIGURE 4. The first meeting of former congenital fellows of Dr Spray, "The Spray Society.” Dr Spray has trained more than 42 fellows, including 28 from the United States and 14 fellows from 10 countries.

they are not good teachers. But if I were asked "What is Dr Spray's greatest single quality?" I would say that he is a courageous and generous teacher of congenital heart surgery. In 1993, I was given the opportunity to perform challenging neonatal surgery. Even today I wonder how he had the courage to hand over arterial switch operations and neonatal heart transplants. Even the lung transplants were shared with the residents. Tom has continued to train congenital heart surgeons, and they are now leaders at several centers across the country and around the world. A few years ago Gary Raff, the Chair of Congenital Heart Surgery at University of California Sacramento, organized a meeting of congenital heart surgeons who were trained by Tom Spray. A photograph of that first meeting is shown in Figure 4. Although others may find it difficult to assess Tom's expression, I have come to know that this is his happy face. Dr Spray has trained more than 42 congenital heart surgeons, including 28 fellows from the United States and 14 fellows from 10 other countries.

I recently had the opportunity to sit down with Dr Spray and get his impressions on his remarkable career and the pathway to the presidency of the AATS. He mentioned more than once how fortunate he was and how his pathway was marked by serendipity. He spoke about how his interest in electron microscopy led him to Haverford College and how those skills gave him a head start at Duke University Medical School and the NIH. One could attribute these comments to modesty, but my impression was that he genuinely believed it! Although a certain degree of luck is usually a part of success, I would say that more accurately luck favors the prepared mind, and certainly Dr Spray had a wellprepared mind.

Dr Spray arrived at the Children's Hospital of Philadelphia and University of Pennsylvania in October of 1994. There, he again demonstrated true leadership and program building qualities. He was able to recruit, support, and develop remarkable talent and established a congenital heart-surgery training program at the Children's Hospital of Philadelphia. Dr Spray has performed more than 10,000 operations during his 20-year career.

In his presidential address "The Quality Conundrum,", Dr Spray spoke of the many challenges facing our specialty today. The digital age has resulted in a flood of data on practitioners, hospitals, and health systems. We are drowning in data and nonetheless thirsting for truth. He spoke of the challenges of public reporting of surgical results without adequate risk adjustment or education of what the results really mean. He spoke of the dangers that this could pose to high-risk patients who may be denied a chance at lifesaving surgery and how public reporting could stifle innovation. He spoke of the ongoing and largely unmet challenge of educating the public on surgical results. He spoke of the challenges of training the next generation of cardiothoracic surgeons within the restraints of the 80-hour workweek even as this next generation will face more challenging, higher-risk patients. There are no validated studies to suggest improvement in patient outcome or resident competence; indeed, the pass rates for the American Board of Thoracic Surgery examinations appear to have decreased. He spoke of the challenges of arbitrary and unsupported 
quality metrics that may be used to grade surgeons and hospitals, and even to limit reimbursement. He warned how best practice consensus guidelines and quality metrics can result in wrong and dangerous consequences for patients and penalties for physicians despite the dearth of highquality evidence to support these practices. Dr Spray spoke of the private insurance industry and the fundamental unresolvable conflict between profit and the best care for the patient. What is the solution to this riddle? Dr Spray pointed out that our specialty has always sought to provide highquality care to our patients. The AATS has developed its mission to model quality and excellence in areas of clinical care, teaching, and research. The AATS has supported leadership development and surgeon-led research. We must continue to educate the public, politicians, and the press on the limitations and unintended consequences of wellmeaning but poorly defined health care initiatives, so we can be at the center of the development of new health care policy and become the solution to the quality conundrum.

\section{References}

1. Spray TL. The quality conundrum. J Thorac Cardiovasc Surg. 2009;138:1053-9.

2. Finger I, Fishbein GP, Spray T, White R, Dilworth L. Radioimmunoassay of Paramoecium surface antigens. Immunology. 1972;22:1051-63.

3. Waugh RA, Spray TL, Sommer JR. Fenestrations of sarcoplasmic reticulum. Delineation by lanthanum acting as a fortuitous tracer and in situ negative stain. J Cell Biol. 1973;59:254-60.

4. Spray TL, Waugh RA, Sommer JR. Peripheral couplings in adult vertebrate skeletal muscle. Anatomical observations and functional implications. J Cell Biol. 1974;62:223-7.

5. Spray TL, Roberts WC. Structural changes in porcine xenografts used as substitute cardiac valves. Gross and histologic observations in 51 glutaraldehydepreserved Hancock valves in 41 patients. Am J Cardiol. 1977;40:319-30.
6. Ferrans VJ, Spray TL, Billingham ME, Roberts WC. Structural changes in glutaraldehyde-treated porcine heterografts used as substitute cardiac valves Transmission and scanning electron microscopic observations in 12 patients. Am J Cardiol. 1978;41:1159-84.

7. Spray TL, Roberts WC. Structural changes in Hancock porcine xenograft cardiac valve bioprostheses. Adv Cardiol. 1978;22:241-51.

8. Weinhaus L, Canter C, Noetzel M, McAlister W, Spray TL. Extracorporeal membrane oxygenation for circulatory support after repair of congenital heart defects. Ann Thorac Surg. 1989;48:206-12.

9. Canter CE, Sekarski DC, Martin TC, Guitierrez FR, Spray TL. Intraoperative evaluation of atrioventricular septal defect repair by color flow mapping echocardiography. Ann Thorac Surg. 1989;48:544-50.

10. Spray TL, Huddleston CB, Canter CE. Technique of transplantation for hypoplastic left heart syndrome with left superior vena cava. Ann Thorac Surg. 1993:55:779-81.

11. Canter CE, Saffitz JE, Moorhead S, Gutierrez FR, Bolman RM, Spray TL. Early results after pediatric cardiac transplantation with triple immunosuppression therapy. Am J Cardiol. 1993;71:971-5.

12. Kouchoukos NT, Davila-Roman VG, Spray TL, Murphy SF, Perrillo JB Replacement of the aortic root with a pulmonary autograft in children and young adults with aortic-valve disease. $N$ Engl J Med. 1994;330:1-6.

13. Marino BS, Wernovsky G, Rychik J, Bockoven JR, Godinez RI, Spray TL. Early results of the Ross procedure in simple and complex left heart disease. Circulation. 1999;100(19 Suppl):II162-6.

14. Spray TL, Mallory GB, Canter CB, Huddleston CB. Pediatric lung transplantation. Indications, techniques, and early results. J Thorac Cardiovasc Surg. 1994;107:990-1000.

15. Bridges ND, Mallory GB Jr, Huddleston CB, Canter CE, Sweet SC, Spray TL. Lung transplantation in children and young adults with cardiovascular disease. Ann Thorac Surg. 1995;59:813-21.

16. Mendeloff EN, Spray TL, Huddleston CB, Bridges ND, Canter CB, Mallory GB Jr. Lung transplantation for congenital pulmonary vein stenosis. Ann Thorac Surg. 1995;60:903-7.

17. Bridges ND, Mallory GB, Huddleston CB, Canter CE, Spray TL. Lung transplantation in infancy and early childhood. J Heart Lung Transplant. 1996;15: 895-902.

18. Hamvas A, Nogee LM, Mallory GB Jr, Spray TL, Huddleston CB, August A, et al. Lung transplantation for treatment of infants with surfactant protein B deficiency. J Pediatr. 1997;130:231-9.

19. Sweet SC, Spray TL, Huddleston CB, Mendeloff E, Canter CE, Balzer DT, et al Pediatric lung transplantation at St. Louis Children's Hospital, 1990-1995. Am J Respir Crit Care Med. 1997;155:1027-35. 